Volume 8

$5-1-2014$

\title{
"Justice for the deceased": victims' participation in the Extraordinary Chambers in the Courts of Cambodia
}

Helen Jarvis

Former Chief of the Victims Support Section of the ECCC

Follow this and additional works at: https://digitalcommons.usf.edu/gsp

\section{Recommended Citation}

Jarvis, Helen (2014) '"'Justice for the deceased": victims' participation in the Extraordinary Chambers in the Courts of Cambodia," Genocide Studies and Prevention: An International Journal: Vol. 8: Iss. 2: 19-27. DOI:

http://dx.doi.org/10.5038/1911-9933.8.2.4

Available at: https://digitalcommons.usf.edu/gsp/vol8/iss2/6

This Articles is brought to you for free and open access by the Open Access Journals at Digital Commons @ University of South Florida. It has been accepted for inclusion in Genocide Studies and Prevention: An International Journal by an authorized editor of Digital Commons @ University of South Florida. For more information, please contact digitalcommons@usf.edu. 


\title{
"Justice for the deceased": victims' participation in the Extraordinary Chambers in the Courts of Cambodia
}

\author{
Helen Jarvis \\ Former Chief of the Victims Support Section of the ECCC
}

\begin{abstract}
The participation of victims of mass crimes is being taken to new levels in the Extraordinary Chambers in the Courts of Cambodia (ECCC) as it brings criminal prosecution for serious crimes committed during the period of Democratic Kampuchea (1975-1979). In addition to being called as witnesses to the crimes being charged, the ECCC has provided the opportunity for some 4,000 victims to play a direct role as Civil Parties. Civil Party status in a criminal trial is a feature known in various civil law systems, but has not been provided in any of the international or what are sometimes called "internationalized" criminal tribunals and so the ECCC had to develop its own procedures in its Internal Rules. Victims' participation may be considered one of the ECCC's main contributions to the development of international justice.
\end{abstract}

Keywords: ECCC; Khmer Rouge; victims' participation; transitional justice; Cambodia; United Nations; civil law

"On 7 January 1979, I never imagined that I would be sitting before the Chamber this very day. It is my great honour to sit and explain things to this huge Chamber. I want nothing else. The thing I want is intangible; it is justice for the deceased." These are the words of Mr Vann Nath, one of the handful of survivors of the S-21 prison and one of Cambodia's most renowned painters, who was the very first person called to give testimony before the Trial Chamber, on 29 June 2009. ${ }^{1}$

Mr Chum Mey, another survivor of S-21, stated: "I am a victim of Tuol Sleng. I know what happened in Tuol Sleng. We have to tell our children and grandchildren in the next generation about this, and we have to tell the world about this. I come every day because I consider the court as history. I am now 79 years old, and I am doing this for the sake of the young generations to fully understand what happened.... Some people say that the court takes too much time. They just yell from the outside without knowing what is being done. They know nothing. You should consider a Khmer saying: "Cooking too long, it would be burned; cooking too little, it would be raw".

Ms Im Sunthy, the widow of Professor Phung Ton, the Rector of the Faculty of Law and a diplomat during the 1960s, who was killed at S-21 in 1976, gave the following testimony in court: "I am here to actually pay homage to the dead souls of my husband and my father and the lost family members. Some people say that I am here to take revenge but it is not true. I am here to find justice for my husband. I am here to reveal the truth why people were killed, why these barbaric acts were inflicted onto the victims."

Mr Tolors Kâsim, also from Kampong Cham, explained his motivation: "First, I want the court to seek justice on behalf of our ethnic group ${ }^{4}$ because we represent Islam. I am concerned about the return of the religious terminators. Secondly, I want collective reparations ${ }^{5}$ so that we can build a school in our village as evidence to show the young generations the extreme destruction in our village caused by the Pol Pot regime. When we returned here, the village was empty; thus, this to-be-built-house or building will be the evidence."

The participation of victims of mass crimes is being taken to new levels in the Extraordinary Chambers in the Courts of Cambodia (ECCC) as it brings criminal prosecution for serious crimes committed during the period of Democratic Kampuchea (1975-1979). At the moment, when one trial has been completed and a second is now under way, it is timely to analyse the challenges, successes and failures of this experience.

As in many other national or international courts, in the ECCC victims may be called as witnesses to the crimes being charged. But the ECCC is providing another and hopefully more meaningful avenue for the victims to play a direct role as Civil Parties -- participating in the case in support of the Prosecution, with the right to their own lawyers, to propose evidence and witnesses, to make their own statements and to question the accused directly in court, and in their own right to make a civil claim for moral and collective reparations. This Civil Party status in the criminal case is a feature known in various civil law systems, but has not been provided in any of the international or what are sometimes called "internationalized" criminal tribunals.

More than 8,000 people have filed complaints with the Court, describing the crimes they experienced between 1975 and $1979 .{ }^{8}$

In early 2012, the ECCC completed its first case (Case 001), in which Kaing Guek Eav, better known by his revolutionary name Duch, was charged with crimes against humanity, war crimes and national crimes of 
murder and torture for acts resulting in the deaths of more than 12,000 people carried out while he was in charge at S-21 (often known as Tuol Sleng - the apex of Democratic Kampuchea's system of security prisons). The Trial Chamber judgment pronounced on 26 July 2010 found Duch guilty and sentenced him to 35 years' imprisonment. All parties appealed, and the Supreme Court Chamber's final judgment confirmed those convictions and increased the sentence to life imprisonment. ${ }^{9}$

The second case (Case 002) involves four accused, alleged to be the surviving "senior leaders" of the Khmer Rouge regime and responsible for mass crimes. Following the judicial investigation (from 2007 to 15 September 2010), their trial commenced with the Initial Hearing held in late June 2011. On 17 November 2011, the Trial Chamber decided to sever one defendant (Ieng Thirith, former Minister for Social Action) from the trial on grounds of her mental unfitness. This left three accused on trial: Nuon Chea (widely known as Brother Number Two after Pol Pot, who died in 1998), Khieu Samphan (former Head of State and of the parliament), and Ieng Sary (former Foreign Minister), who died in March 2013 leaving only two standing trial for genocide, crimes against humanity, war crimes and the domestic crimes of murder, torture and religious persecution. ${ }^{10}$

The Trial Chamber also decided to sever the case into several trials, the first known as Case 002/01, focusing on the evacuations of the population in 1975 and again in 1976, and on the execution of Lon Nol officials in April 1975, concluded evidentiary hearings on July 23, 2013. Final Statements were heard in October 2013 before the Trial Chamber retired to consider its judgment, expected to be issued in the second quarter of 2014. ${ }^{11}$ Also on July 23, 2013, the Supreme Court Chamber issued an order that the Trial Chamber's hearing of further charges in Case 002 should include at least those relating to S-21 (Tuol Sleng), a work-site and a security center, as well as genocide. ${ }^{12}$

Meanwhile, since late 2009 the Co-Investigating Judges have been considering whether another five people should be charged, as proposed by the International Co-Prosecutor but opposed by the National CoProsecutor. This number fell to four when one Suspect died in mid-2013. ${ }^{13}$

\section{Victim participation at the ECCC}

In the first trial, of Duch, 90 victims participated as Civil Parties in the proceedings, and 22 of them testified in court. ${ }^{14}$ Some 3,850 victims have Civil Party status in Case $002,{ }^{15}$ far exceeding the numbers in any previous trials of such mass crimes in any international/ized judicial setting. ${ }^{16}$ What were the motivations of so many Cambodian victims to give up an extended amount of time and expose themselves to public gaze, emotional turmoil and even trauma from recalling their suffering and hearing the brutal crimes described in gruesome detail day after day? Five victims who were witnesses or Civil Parties in Case 001 explained what the process means to them in a video entitled The Long-awaited Day, made for the Victims Support Section of the ECCC.

Mr Uch Sunlay from the province of Kratie, explains what motivated him to apply to be a Civil Party in Case 002: "I did not just think about applying to be a Civil Party yesterday or today. I have been ready for years. I was determined that once there is a court, either national or international, I will apply as a Civil Party because I have suffered from great pain; this is my first intention. Secondly, I lost a lovely father. Thirdly, I lost my wife and all my children, and all my in-laws, including my parents-in-law, brothers and sisters-in-law simply because they were accused as KGB in that regime.

"I applied as a Civil Party in order to sue the senior leaders and those most responsible in the Democratic Kampuchea regime for their killings. Firstly, I want them punished by the law for the atrocities. Secondly, I want both national and international courts as well as the whole wide world to acknowledge that there were killings, homicide and a killing field regime in Cambodia. Thirdly, I want my children who died recorded in the history for the younger generations. My beloved wife and children were all killed during this notorious regime. I was determined that whenever a court would be established, regardless of what they can do or cannot do as long as it prosecutes those leaders, I will feel relieved. The souls of the deceased ones cannot claim for justice; thus, a survivor, such as a husband, shall seek justice for his wife, children and babies. This is the reason I have applied as a Civil Party to request the court, particularly the national officials and judges, to conduct research, investigation, and prosecution."

"I want a judgment for the establishment of a symbolic memorial for storing the remains of the victims, or the remains can be stored at a pagoda in Kratie so that we will feel relieved and those who died will also rest peacefully in heaven. And we who have rid ourselves of pain, suffering and tension from our hearts and emotions, will be ready to develop our society to be more advanced and prosperous."17 


\section{Legal and administrative framework for victim participation}

Victim participation at the ECCC has not been without controversy, rising at times to heated argument and even bitter conflict. The roles and rights of Civil Parties and the level of support extended to them have proved to be among the most difficult and ongoing problems the court has had to face as it grappled with the realities and emotions of this sensitive issue.

The whole question of victim participation as Civil Parties was considerably complicated by the fact that administratively, the ECCC was completely unprepared for any role for Civil Parties. This was one of the clearest instances in which the United Nations' Technical Assessment Mission simply applied the formulas from the ad hoc tribunals of the ICTY and ICTR and the Sierra Leone Special Court without regard to the very different legal and judicial context of Cambodia. Neither the budget nor staffing tables for the ECCC included any provision for Civil Parties. The first Deputy Director of Administration (who had previously served in the ICTR) expressed this approach clearly when she stated at the first press conference held in the new premises of the Court that "the only role for victims in the ECCC would be as witnesses".18

However, the foundation documents for the ECCC (a domestic Law and an Agreement between the Cambodian government and the United Nations ${ }^{19}$ ) stipulate that the Court shall utilize Cambodian criminal procedure, except in certain circumstances when such procedure is silent, internally contradictory, or when it conflicts with international standards. ${ }^{20}$ And Cambodian criminal procedure includes the possibility for victims to participate as Civil Parties in criminal proceedings.

Further, while neither the Law nor the Agreement made specific mention of the role of Civil Parties, the Law did envisage victims as Parties to the cases in that Article 36 (new) stipulated the rights of victims to appeal decisions of the Trial Chamber. In its preparatory work for the establishment of the Court, the Cambodian Government Khmer Rouge Trials Task Force anticipated that one of the areas requiring early decision would be how to apply Cambodian procedure allowing victims participation and claims for reparations in circumstances in which millions of people were victims. The first edition of An Introduction to the Khmer Rouge Trials, an information booklet published by the Task Force in 2004, included the following cautious formulation:

Will victims be entitled to compensation? Under the current Cambodian law on criminal procedure, victims may claim reparation in criminal cases for damages they suffered from the crimes being tried. It is not yet clear whether or how the Extraordinary Chambers will hear such claims. It is difficult to imagine how the many millions of Cambodian victims could receive anything more than symbolic compensation. ${ }^{21}$

A draft Internal Procedures and Regulations, developed by Dr. Gregory Stanton for and with the Task Force, ${ }^{22}$ was presented to the ECCC judicial officers (judges and co-prosecutors) in early July 2006. This draft made provisions for victims to apply to participate in the hearings (Article 89); to appoint legal representatives, even envisaging the probable need for common legal representation for groups of victims and for legal assistance for representation (Article 90); and to claim reparations, including remedies such as restitution, compensation and rehabilitation (Article 94$){ }^{23}$

Judges from common law systems (who constituted the majority of international judges) were adamant that full victim participation, as Civil Parties would present an impossible burden on the court in terms of finances and time. Judges from civil law systems, who were used to Civil Parties even in mass crimes, were equally adamant that the ECCC had to accommodate Civil Parties, as it had no power to limit rights that are clearly and unambiguously provided under Cambodian criminal procedure, so it seemed inevitable that some compromise would emerge, providing a limited form of victim participation and claims for reparations.

The judicial officers established a Rules Committee (which consisted solely of judges from civil law countries). Its draft of the Internal Rules presented to the November 2006 First Plenary Session provided for normal Civil Party action by victims including legal representation and claims for reparations, but including the following caveat (with an undecided adjective): "Injury may be compensated by awarding [proportionate] damages. The Chambers may also award collective or symbolic reparation."

After intense debate in many meetings of the Rules Committee, and as one of the very final matters in the Internal Rules to be resolved, the Plenary Session in June 2007 adopted a severely limited right to reparations, as follows:

Rule 23-- Civil Party action by victims [...]

11. Subject to Article 39 of the ECCC Law, the Chambers may award on 
collective and moral reparations to Civil Parties. These shall be awarded against, and be borne by convicted persons.

12. Such awards may take the following forms:

a) An order to publish the judgment in any appropriate news or other media at the convicted person's expense;

b) An order to fund any non-profit activity or service that is intended for the benefit of Victims; or

c) Other appropriate and comparable forms of reparation..$^{24}$

The Office of Administration responded by establishing a small Victims Unit (later known as the Victims Support Section), allocating unspent funds from other budget lines, and was lucky to be able to recruit an experienced staffer from the ICTY to come in as interim Deputy Head of the Unit. ${ }^{25}$ However, with such a late start, and with woefully inadequate funds, the Victims Unit was very quickly overwhelmed as the enormity of its task became evident.

How to reach the unknown number of victims throughout the country, inform them of their rights to participate and encourage the filing of complaints and civil party applications was a major challenge. A working relationship was quickly developed between the Victims Unit and a number of NGOs that had already established or were ready to establish programs relating to Khmer Rouge victims. The most active of these "intermediary organizations" included the Khmer Institute for Democracy (KID), the Documentation Center of Cambodia (DC-Cam), the Cambodian League for the Promotion and Defense of Human Rights (Licadho) and the Cambodian Human Rights Action Committee (CHRAC).

While in its first year the Victims Unit had no specific resources for outreach, such funding was already flowing to the intermediary organizations from a number of donors (notably the German and French governments, and the European Union). And in early 2009 the German Government (through GTZ) made a significant direct grant to the Victims Unit. ${ }^{26}$

Forums were held throughout the country, and teams assisted victims in completing the somewhat complex form the ECCC had developed for them to file a complaint and to apply for status as a Civil Party.

While under Cambodian criminal procedure, applications may be filed at any time up until the final submissions at the closure of the trial, the Internal Rules of the ECCC were more restrictive, initially providing that any application had to be lodged 10 days before the start of the trial. ${ }^{27}$ As a result of the fact that Case 001 was limited to crimes relating to a single crime site (the security center of S-21 and its ancillary units) and because these procedural decisions were not made until almost the time of the Closing Order, a relatively small number of victims applied before that deadline -- 94, of whom 90 participated.

In Case 002, the Victims Unit and the intermediary organizations made a strong and concerted outreach effort, and 3,988 victims applied in Case $002 .^{28}$ The Co-Investigating Judges, who had the initial responsibility of deciding, recognized only some 50\% of these Civil Party applicants for Case 002, but on appeal the Pre-Trial Chamber took a much more expansive approach, admitting 3,850 Civil Parties, close to 100\% of those who had applied.

\section{Legal representation}

Even after adoption of Internal Rules allowing for Civil Party participation, the ECCC did not initially provide any financial support for legal representation for Civil Parties. This contrasted sharply to the Defense, which was generously supported from the international side of the budget, on the basis of the Law and Agreement provisions for legal support for any Accused deemed to be unable to afford their own lawyers. ${ }^{29}$ All five Accused in Cases 001 and 002 were provided with legal teams funded through a legal aid fund administered through the Defense Support Section.

No such support from the Court was offered for Civil Parties. Lawyers, mostly funded from foreign governments through the intermediary organizations, offered legal pro bono representation. Legal teams emerged, not on the basis of inherent or identified differentiation of interest among groups of Civil Party applicants, but rather from their relationship to the intermediary organizations which had facilitated the collection of their applications for Civil Party status.

Four Civil Party legal teams were recognized by the Trial Chamber and, in a mirror image of the Defense 
and Prosecution, both national and international co-lawyers were recognized for each team, meaning that eight Civil Party co-lawyers were entitled to be present in court at any one time and to speak on most issues. ${ }^{30}$ As can be imagined, this presented not only logistical difficulties to the court, including space requirements, but also the difficulty of developing and arguing a coherent legal strategy, with co-lawyers often presenting repetitive or, at times, contradictory arguments. The cumbersome nature of this arrangement, with a total of six national and eleven international co-lawyers recognized for Civil Parties, was exacerbated by the fact that the team of international co-lawyers for Avocats sans Frontières (Lawyers without Borders) appeared on a rotating basis, and were each generally in Cambodia for only three weeks at a time.

Although the ECCC provided some administrative and logistic support, mainly through the Victims Unit, Civil Party legal representation was precarious, with co-lawyers subject to donors' goodwill to provide financial assistance, office accommodation, transport to meet their clients and the other basic requirements to discharge their professional obligations. It soon became painfully obvious that such a haphazard basis for Civil Party legal representation could not be continued in Case 002, a much more complex case in every way, and in which thousands of Civil Parties would be participating.

Accordingly, in early 2009 a working group within the ECCC ${ }^{31}$ began developing a proposal for the Rules Committee, considering various ways in which the Internal Rules could be amended to provide for more coordinated and assured Civil Party legal representation. Meanwhile, the Trial Chamber itself decided to stimulate a broader discussion, including with lawyers, intermediary organizations and other NGOs on the issue of how to ensure effective legal representation for Civil Parties without jeopardizing the efficient functioning of the Court, especially in the light of the large number of Civil Parties expected in Case 002. ${ }^{32}$

Many advocates for victims' rights feared their curtailing through this process and argued vociferously against any change in such a direction. ${ }^{33}$ Such a fear was perhaps unnecessarily stoked by the inclusion in the first drafts of the Trial Chamber's options paper the option of amending the Internal Rules to remove Civil Party participation completely, which was never really a feasible course of action, given that the ECCC was in a civil law jurisdiction.

Following lengthy discussion and hot debate, the Plenary Session of judicial officers adopted Revision 5 of the Internal Rules on February 9, 2010, extensively revising the legal representation of Civil Parties at the ECCC, by which "Civil Parties at the trial stage and beyond shall comprise a single, consolidated group, whose interests are represented by the [national and international] Civil Party Lead Co-Lawyer [...] supported by the Civil Party Lawyers [...] Civil Party Lead Co-Lawyers shall file a single claim for collective and moral reparations. ${ }^{34}$

Several new articles were added, in which the role of the Lead Co-Lawyers was defined as to "ensure the effective organization of Civil Party representation during the trial stage and beyond, whilst balancing the rights of all parties and the need for an expeditious trial within the unique ECCC context". 35

This novel approach went into operation in Case 002 and, at least up until the end of Case 002/01, formed a more coherent framework for Civil Party legal representation, and a far more efficient functioning of the trial, without substantially curtailing their rights. While at the trial stage they were now consolidated into a single group, individual Civil Parties still retained their own co-lawyers, and the Lead Co-Lawyers gave many opportunities to these co-lawyers to speak in court, on both matters relating to their own clients and certain legal issues in which they had a particular interest or point of view.

\section{Victims' associations}

In the Cambodian situation of generalized suffering and privation of the entire population during the Khmer Rouge period, within the country there was little concept of distinguishing a separate category of "victims of the KR". During the 1980s the government undertook numerous nationwide documentation, literary, and artistic programs, and the experience of victims was taught in schools. In countries with large Cambodian refugee populations like France, the US, Canada, and Australia, community and support committees were established; their focus included psychological and medical assistance for the large number of individuals suffering trauma, as well as documentation of the crimes they experienced, as part of the campaign to seek justice.

Following the enactment of the ECCC Law and Agreement, in France an Association "Justice pour le Cambodge" (Justice for Cambodia) was formed in 2004, dedicated to promoting the rights of the victims of the Khmer Rouge and, in particular, to assisting and representing them before the ECCC. Justice for Cambodia joined with several other organizations to establish the Collective for Victims of the Khmer Rouge, 
which produced a white paper on victims' rights, set up a branch in Cambodia and proceeded to find legal representation for some 59 victims who wished to participate in the coming trials. In Cambodia, at least two more victims' associations were established, and their evolution reveals the complexity of the relationship of victims to the formal process of the ECCC.

\title{
The Association of Khmer Rouge Victims in Cambodia (AKRVC)
}

The AKRVC describes itself as "independent of any political or religious affiliation-a network of survivors of the 1975-79 killing fields who are joined in the fellowship of suffering, in the demand for justice, and in the work for a just peace. The members of the Victims Association are from overseas and spread across the provinces and capital of Cambodia." The AKRVC was founded by Theary C. Seng, the first Civil Party to be recognized by the ECCC in Case 002, who established the Civil Parties of Orphans Class, of whom she was one. Theary Seng, a well-known political activist, gained considerable publicity for the AVKRC and the Orphans Class before becoming disenchanted with the ECCC and withdrawing her Civil Party status in November 2011. ${ }^{36}$

\section{Ksaem Ksan (Victims Associations of Democratic Kampuchea)}

Ksaem Ksan was founded in 2009. Among its leading founders are two survivors from S-21, Chum Mey and Bou Meng, as well as a number of Civil Parties in the ECCC. The Association was established to assist its members to aims to participate in all stages of the ECCC process, to provide spiritual and material support and an improved living standard to its members, and to conduct outreach to new generations so that they understand better the history of Democratic Kampuchea in order to prevent a recurrence of such a regime.

\section{Reparations}

As mentioned above, the ECCC Law's Article 39 and Internal Rule 23 provide for the award of only collective and moral reparations to Civil Parties, against and borne by convicted persons. In Case 001, the Trial Chamber interpreted the Internal Rules narrowly, ruling out almost all reparation claims filed by the Civil Parties, and awarding only the publication of their names and a compilation of apologies by Duch during the trial.

Ksaem Ksan reflected the views of most victims in a press release issued on 24 February 2012 after the Supreme Court Chamber issued its final judgment:

\begin{abstract}
On behalf of Victims Association of Democratic Kampuchea "Ksaem Ksan" civil parties in Case 001, we wish to express our sadness with the so-called collective and moral reparation the ECCC has decided to grant the civil parties in the form of compiled declarations of apologies of the convicted Duch during the course of the trial. As we pointed out during our testimonies in the courtroom, we do not believe in the sincerity of the apologies made by Duch. We think that his declaration of regrets was only a way to obtain mitigating circumstances from the trial chamber. As a proof of what we stated here above, in the last day of trial, Duch has asked the court for his release and to be free from any prosecution. How could one sincerely think that a simple compilation of these declarations of Duch constitute a moral reparation for the victims? In future, we will continue to monitor the honesty of the convicted Duch during his testimony of substantial hearing in case $002 .{ }^{37}$
\end{abstract}

Following widespread dissatisfaction with the ECCC's reparations regime, as it unfolded in Case 001, the judicial officers amended the Internal Rules in September 2010, allowing a much broader approach. Firstly, reparations may now include not only awards ordered against the convicted person, but also other projects "designed or identified in cooperation with the Victims Support Section and [which] have secured sufficient external funding." Secondly, the Victims Support Section is "entrusted with the development and implementation of non-judicial programs and measures addressing the broader interests of victims. Such programs may, where appropriate, be developed and implemented in collaboration with governmental and non-governmental organizations external to the ECCC."

The Lead Co-Lawyers for Civil Parties and the Victims Support Section have since then been working with victims associations and intermediary organizations as well as communicating with the Royal Government of Cambodia regarding certain issues that fall within its competence, to draft appropriate reparations and nonjudicial programs and measures, which it is hoped will provide more meaningful recognition and response to the suffering of victims of the KR regime. 


\section{Conclusion}

The process of judicial accounting embodied in the ECCC is being done late, and much has been lost in the more than 30 years since the end of the Khmer Rouge regime. Physical evidence has been washed away, documents have been lost, memories have faded and, above all, many people have died - some who should be on trial, others who should have had the chance to tell their stories in court, and millions of people who should have had the chance to see justice done.

The cost of this passage of time is being acutely felt as Case 002 unfolds. As mentioned above, one defendant (Ieng Thirith) was severed from the trial, and her husband (Ieng Sary) died, while the fragile health condition of the remaining two defendants continues to dog the proceedings. Over the same period, a number of Civil Parties and witnesses scheduled to give testimony have passed away, or become too frail to testify, while most of those who have testified have revealed limits to both their physical and mental capacities.

As mentioned above, in order to speed up the process, the Trial Chamber decided to break Case 002 into several segments, but the trial phase of the initial segment took more than two years, while a final judgment by the Supreme Court Chamber is still some years away. Whether even this first segment of Case 002 will reach a conclusion is by no means assured.

The ECCC is still in train, not yet a historical event to be evaluated. Until it finishes its work, one cannot venture to conclude whether or how well this process of judicial accounting was achieved and how it contributed to Cambodia's struggle to free itself from the weight of this brutal period in its recent history.

What can be stated unequivocally, however, is that millions of Cambodians are watching the process intently. By July 2013, more than 200,000 Cambodians had visited the court. The courtroom holds some 500 people in the public gallery, and its proceedings have been broadcast live on national television and radio. In a poll taken towards the end of Case 001 , more than $80 \%$ of those surveyed reported being aware of the ongoing process, $60 \%$ having themselves seen it on television and $70 \%$ believing it is providing justice. ${ }^{38} \mathrm{~A}$ flowering of public and private reflection, research and comment is under way in Cambodia, really seizing popular attention alongside the judicial process. Week after week, month after month, programs and activities are carried out throughout the country - on screen, on stage, in print, in schools, in wats, mosques and churches, at memorial sites, in meetings, forums, discussions, and therapy sessions.

Precisely because it was a pioneer among internationalised courts in providing for victim participation as Civil Parties, the ECCC had no precedents or road maps on which to rely, but had to develop its own procedures, a process that was severely impeded by the unfamiliarity of common law judges and United Nations administrators with this element of civil law. Lack of certainty, and changing rules along the way led to unease, anxiety and suspicion. Although the Internal Rules were eventually amended to provide more clarity and a broader approach to reparations, the sense of disappointment from unfulfilled expectations might have been avoided if the issue had been given sufficient attention and weight at the time of the establishment of the court. Despite all these problems, however, the participation of some 4,000 victims as Civil Parties may be considered one of the ECCC's main contributions to the development of international justice.

\section{End Notes}

1. Vann Nath, excerpt from the English transcript of testimony on 29 June 2009, in proceedings of the ECCC Trial Chamber in Case 001; Kaing Guek Eav, alias Duch, available on the ECCC web site at http://www.eccc.gov.kh/en/documents/court/ transcript-proceedings-\%E2\%80\%9Cduch\%E2\%80\%9D-trial-trial-day-34 (accessed 10 June 2012). It should be noted that Vann Nath did not apply for Civil Party status, testifying instead as a witness.

2. Civil Party Chum Mey interview at Tuol Sleng Genocide Museum (former S-21 prison), included in The long-awaited day: victim participation in the ECCC, video production by the Victims Support Section of the ECCC, 2009.

3. Civil Party Im Sunthy, excerpt from the English transcript 19 August 2009 http://www.eccc.gov.kh/en/documents/court/ transcript-proceedings-\%E2\%80\%9Cduch\%E2\%80\%9D-trial-trial-day-61 (accessed 10 June 2012).

4. Civil Party Tolors Kâsim is a member of the Cham minority.

5. The Internal Rules of the ECCC (Article 23) provide that Civil Parties may claim "collective and moral reparations" for harm suffered. All versions of the Internal Rules may be accesses on http://www.eccc.gov.kh/en/document/legal/internal-rules

6. Tolors Kâsim interview in The long-awaited day.

7. These include the International Criminal Tribunal for the former Yugoslavia (ICTY), the International Criminal Tribunal for Rwanda (ICTR) and the Special Court for Sierra Leone (SCSL), all of which have more common law than civil law features.

8. For more detail on victim participation in the ECCC, see the Victims Support Section of the ECCC web site http://www.eccc. gov.kh/en/victims-support (accessed 10 June 2012). 
9. See the ECCC web site for the text of the Supreme Court Chamber's final judgment of 3 February 2012 (Document F28) http://www.eccc.gov.kh/sites/default/files/documents/courtdoc/Case\%20001AppealJudgementEn.pdf and the Trial Chamber Judgment of 26 July 2010 (Document E188) http://www.eccc.gov.kh/en/documents/court/judgement-case-001 (accessed 10 June 2012).

10. For details of the charges in the indictment, see the redacted public text of the Closing Order in Case 002 issued by the CoInvestigating Judges on 15 September 2010, (Document D427) http://www.eccc.gov.kh/en/documents/court/closing-order (accessed 10 June 2012).

11. For details of the conclusion of evidentiary hearings in Case 002/01, see the ECCC's Court Report, March 2014, p.4. However, as at the time of finalizing this article (early May 2014) no date had been set, and it seems likely that the delivery may be postponed into the third quarter of this year.

12. These charges were included in the Trial Chamber's Decision on Additional Severance of Case 002/02 and Scope of Case 002, issued on April 4, 2014. The Supreme Court Chamber also proposed that the Trial Chamber consider establishing a Second Trial Panel, but this option was rejected by the Trial Chamber, which went on to make preparations for hearing Case 002/02 after its judgment in Case 002/01 will be handed down, (E301/9/1 (accessed April 8, 2014). For details of the Supreme Court Chamber's decisions see its Decision on Immediate Appeals Against Trial Chamber's Second Severence of Case 002 E284/417 and its Order on a Second Trial Panel, (E284/471) (accessed 23 July 2013).

13. See Statement by the International Acting Co-Prosecutor, 8 September 2009 http://www.eccc.gov.kh/sites/default/files/media/ ECCC Act Int Co Prosecutor 8 Sep 2009 \%28Eng\%29.pdf (accessed 11 June 2012).

14. In its judgment of 26 July 2010 (Case 001), the Trial Chamber admitted only 66 of the Civil Party applicants, ruling that the other 24 did not sufficiently establish their link to the crimes charged in this particular case. Most of these Civil Parties successfully appealed against their rejection, and were ultimately recognised in the final judgment issued by the Supreme Court Chamber on 3 February 2012.

15. See the redacted public text of the Pre-Trial Chamber Decision on Appeals Against Orders of the Co-Investigating Judges on the Admissability of Civil Party Applications, (Case 002), 24 June 2011, Documents D411/3/6 and D404/2/4). http:// www.eccc.gov.kh/en/document/court/decision-appeals-against-orders-co-investigating-judges-admissibility-civil-party-app (accessed 11 June 2012).

16. There is precedent of mass Civil Party participation in domestic jurisdictions, especially in South America, but the author of this paper has yet to carry out research on which to base any comparative comments or assessment.

17. Civil Party Uch Sunlay, interview for The long-awaited day.

18. Michelle Lee, Deputy Director of Administration in ECCC Press Conference, 9 February 2006, as noted by the author.

19. Law on the Establishment of the Extraordinary Chambers in the Courts of Cambodia for the Prosecution of Crimes Committed During the Period of Democratic Kampuchea, promulgated on 27 October 2004 (NS/RKM/1004/006) and the Agreement Between the Royal Government of Cambodia and the United Nations Concerning the Prosecution Under Cambodian Law of Crimes Committed During the Period of Democratic Kampuchea, signed on 6 June 2003. http://www.eccc.gov.kh/en/ documents/legal/law-establishment-extraordinary-chambers-amended and http://www.eccc.gov.kh/sites/default/files/legaldocuments/Agreement between UN and RGC.pdf (accessed 11 June 2012).

20. Article 33 new of the Law and Article 12.1 of the Agreement.

21. An Introduction to the Khmer Rouge Trials, $1^{\text {st }}$ edition. (Phnom Penh: Secretariat of the Royal Government Task Force, Office of the Council of Minister, 2004) with support from the Australian Government through the Australian Legal Resources International (ALRI), p.17.

22. Some funding support was extended from the Open Society Justice Initiative (OSJI). The team also included Helen Brady, Tara Gutman and Helen Jarvis.

23. Draft Internal Rules, presented to he Judicial Strategic Planning and Development Workshop, July 2006.

24. ECCC Internal Rules adopted 7 June 2007.

25. Ms Wendy Lobwein.

26. In November 2008 the Gesellschaft für Technische Zusammenarbeit (GTZ), tasked by the German Foreign Office, allocated 1.5 million euros over two years to support the work of the Victims Unit.

27. Article 23.4 of the first version of the Internal Rules adopted 7 June 2007.

28. The Internal Rules had meanwhile been changed (Revision 4, dated 11 September 2009) to further limit the time for application until 15 days after the end of the judicial investigation, in order that the status of all Civil Party applicants could be determined before the trial commenced, as their undetermined status during the trial process had been a problem in Case 001.

29. Article 35 (new) of the Law and Articles 13.1 and 17 of the Agreement.

30. The Trial Chamber did not grant the Civil Party lawyers the full range of rights accorded to the Defence and the Prosecution. For instance, they were not permitted to make an Opening Statement, nor to intervene on issues relating to sentencing or of the character of the accused. Details of the issues and the views of the Civil Party Co-lawyers may be found in the Appeal of Group 2 dated 15 September 2009 against the Trial Chamber Decision of 27 August 2009 (Document E169) http://www. eccc.gov.kh/en/documents/court/appeal-co-lawyers-civil-parties-group-2-against-trial-chambers-decisions-exclude-civ (accessed 11 June 2012). 
31. The Working Group consisted of Tarik Abdulhak (then Senior Court Management Officer in the Court Management Section; Wendy Lobwein, Head of the Witness and Experts Support Unit; Keat Bophal (succeeded by Helen Jarvis) Head of the Victims Unit; and Constanze Uhlrich, GTZ Legal Expert in the Victims Unit.

32. Development of the Trial Chamber initiatives was steered by its international Reserve Judge Claudia Fenz.

33. Arguments presented for example in meetings with the Trial Chamber judges and with the Victims Unit, in a submission from Avocats sans Frontières dated 1 December 2009, and in a press statement by the Cambodian Human Rights Action Committee dated 1 February 2010. http://www.chrac.org/eng/CHRAC\%20Statement\%20in\%202010/02_01_2010_CHRAC\%20Press\%20 Release 7th\%20Plenary.pdf (accessed 10 June 2012).

34. Rule 23 (revised)

35. Rule 12 ter Civil Party Lead Co-Lawyers.

36. Theary Seng not only withdrew as a Civil Party but also denounced the ECCC, referring to it as "The Extraordinary Gas Chambers for 003 Victims in the Courts of Cambodia" and depicting then international Co-Investigating Judge Siegfried Blunk as a Nazi. http://www.thearyseng.com/columnist/32-theary-sengs-blog/294-news-coverage-press-release-appealingeccc-decision-lodging-new-application-legal-farce-at-extraordinary-gas-chambers-toward-dismissing-case-003-ocijstatement (accessed 10 June 2012). In a press conference on 15 November 2011, she counterposed a campaign for "poetic justice" to the judicial process, launching a series of dartboards featuring photos of the accused and other she considered to be "likely suspects". Details can be found at various places on her web site.

37. Ksaem Ksan Press Release, "Convicted person DUCH's apologies : a trick to avoid his conviction by ECCC", February 24, 2012. http://www.ksaemksan.info/index.php?nav=home\&cid=25\&lang=en (accessed 10 June 2012).

38. Survey of Cambodian Public Opinion, July 31 - August 26 2009, International Republican Institute, published February 2010 http://www.iri.org/sites/default/files/2010\%20February\%202\%20Survey\%20of\%20Cambodian\%20Public\%20Opinion, $\% 20$ July\%2031-August\%2026,\%202009\%20--\%20Khmer\%20and\%20English\%20version.pdf (accessed 11 June 2012). 